\title{
A Effect of E-Filing on the Behavior of Taxpayers in Annual Tax Return Obligations Against Use of the Actual System
}

\author{
Muhammad Nur \\ \{m.nur@civitas.unas.ac.id\}, Universitas National, Jakarta, Indonesia
}

\section{Arifuddin}

\{arifuddin.mannan@gmail.com\}, Faculty of Economics and Business, Hasanuddin University, Makassar, Indonesia.

\author{
Nursini \\ \{nini_mahmud@yahoo.com\}, Faculty of Economics and Business, Hasanuddin University, Makassar, Indonesia.
}

\author{
Andi Kusumawati \\ \{andiuma88@gmail.com\}, Faculty of Economics and Business, Hasanuddin University, Makassar, Indonesia.
}

\begin{abstract}
The Republic of Indonesia Tax Institute uses modern technology services for annual tax reporting. This study analyzes the effect of e-filing on the behavior of taxpayers who report annual tax obligations on the actual use of the system. Data collection through questionnaires about taxpayers who filled out the tax return but only 93 questionnaires that can be processed. The results of the questionnaire were processed using structural equations which were processed by the LISREL 8.70 program. This research is quantitative. The results of the coefficient of determination (R2) of 0.11 , which means that the simultaneous contribution of $11 \%$ of exogenous variables feels useful, perceived ease of use can explain the diversity of endogenous behavior of the intention variable to be used. The remaining $89 \%$ is influenced by other factors. Recommended for Tax Institutions, continue to improve and add to the benefits of e-filling, as is done in India.
\end{abstract}

Keywords:

E Filing, Perception of Use, Perception of Ease, Behavior Intentions used, Use of the Actual System.

Article Received: 18 October 2020, Revised: 3 November 2020, Accepted: 24 December 2020

\section{Introduction}

Tax Institutionof the Republic of Indonesian as the formulator and implementer of policy and technical standardization in the taxation field, in its 2018 Performance Report continues to make efforts so that tax compliance for tax payers (WP) can be improved. One of them is "modern technology-based services for ease of fulfillment of tax obligations" [1]. The form of service based on modern technology is the use of internet based actual system the form e-filing.

Understanding "e-Filing is a method of submitting electronic reporting annual tax (SPT) that is done online and in real time via the internet on the website of the tax institution (www.pajak.go.id) or an internet service provider company designated by the tax institution" [2]. Data based on 2017 DJP LAKIN and 2018 that Submission of electronic tax returns as of 31 March 2017 there were 3.490 .635 (62.83\%) of the total target of5.555.816 WP, meaning that there were still WPs reporting in conventional tax returns [3]. This data is composed of WP Entity namely SPT 1771, SPT WPOP 1770 and SPT WPOP $1770 \mathrm{~S}$.

The reason there are still taxpayers to report their taxes using conventional Notification, because the Taxation General Provisions Act Number 6 of 1983 which has been changed the third time to Number 28 of 2007 as the parent of the formal tax law does not require tax reporting 
using e-filing which means it is still biased use the Annual Tax Return (SPT) conventionally. Tax reporting using e- filing can be found in PMK. 243/PMK.03/2014 Article 6 paragraph 2, i.e. SPTs in the form of electronic documents can be taken directly by the Taxpayer or by other means determined tax institution. The implementing regulation regarding e filling tax institution issues PER-06/PJ/2014.

Online tax reporting has a mission to make it easier for taxpayers to complete their taxation and help increase state tax revenue. Therefore, there are many benefits from online tax reporting, including cutting time and costs, validation is done to ensure the accuracy of the data entered.

Therefore, use of the actual system form of efiling influenced by factors because it is considered useful/useful (Perceived Useful), easy to use (Perceived Ease to Use) by taxpayers? What about the behavior of taxpayers in this case the intention of data security risks due through the internet to the use of actual system use in reporting financial data? This is at the same time the aim of this research.

Tax administration is anticipating things that might happen by fulfilling tax administration obligations including calculating taxes correctly, paying taxes on time and reporting them on time [4]. So, one tax obligation is to report taxes on time. In India individuals and HUF who require legal audits of $44 \mathrm{AB}$ or companies without eFiling will not be accepted [5]. "ElectronicAnnual Tax Returnthe potential to benefit taxpayers and IRB, but only if it is actually used by Malaysian taxpayers. Thus, the purpose of this study is to identify the factors that influence the taxpayer's decision to use the e-filing system. This study contributes to the e-government literature in two ways. First, this study suggests a simplified version of the TAM model for adoption of e-filing systems. This simplified model contains 3 important variables for electronic archiving; they are considered Perceived Ease of Use (PEOU), perceived usefulness (PU) and perceived risk (PR). In most e-filing studies (Carter et al., 2008;
Fu et al., 2006), PR variables found significant influence in explaining behavioral intentions" [6].

The e-Filing service through the website of the Directorate General of Taxesof the Republic of Indonesia, has been integrated in the DJP Online service, which can be accessed at the following link:

1. For taxpayers who wish to submit their Annual Personal Income Tax return (1770, 1770S, 1770SS) and the Annual Corporate Income Tax Return (1771) can fill out and submit their tax return report on the e-Filing application at DGT Online.

2. For the types of SPT 1770SS and 1770S forms are provided directly in the e- Filing application form. Whereas for the submission of other tax returns, especially types of tax returns 1770 and 1771, e-Filing in DJP Online provides the SPT delivery facility in the form of uploading tax returns that have been made through e-SPT applications or e-FORM, the SPTs that have been made through these applications can submitted online without having to come to the Tax Service Office (KPP).

3. In addition to these facilities and for other types of tax returns, taxpayers can submit tax returns online through one of the ASPs that have been appointed by the Director General of Taxes, namely: "1) www.spt.co.id, 2) www.pajakku.com, 3) www.eform.bri.co.id, 4) www.online-pajak.com, 5) aspbni.bni.co.id, and 6) klikpajak.id" [7]

This research will examine human behavior of the use of information technology, namely e filing in tax reporting. Therefore, "this study uses the theory of Technology Acceptance Model (TAM) designed by Davis (1986)"'[8]. Purpose of TAM is providing an explanation of the determinants of general computer use able to explain user behavior in various end-user computing technologies and user populations. Ideally someone wants a useful model not only for prediction but also for exploration. so researchers and practitioners can identify why certain systems might not be acceptable. and pursue appropriate 
corrective steps.[9] Therefore, the main purpose of TAM. is to provide a basis for tracking the impact of external factors on internal beliefs, attitudes. and intention. TAM believes that two specific beliefs. Perceived usability and perceived ease of use, are the main relevance for computer acceptance behavior " [10].

The research model or concept is:

Source: Davis et al. (1989)

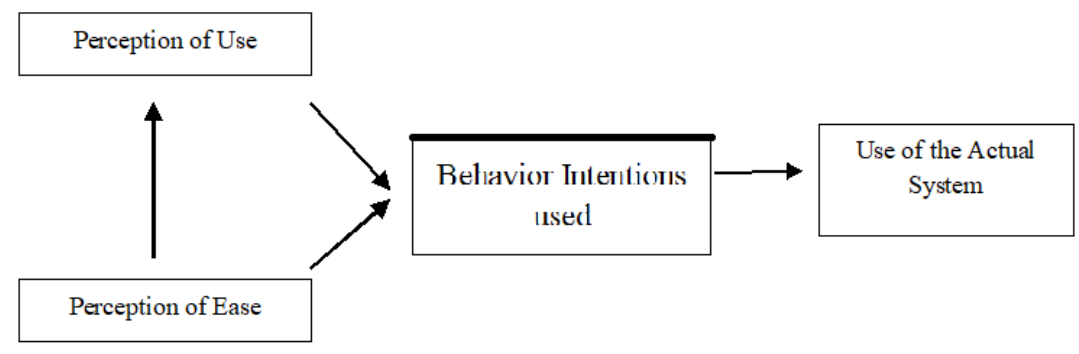

Fig 1. Research Model

\section{$2 \quad$ Research Methods}

Sample selection is a simple random method of the population of "personal taxpayers" who fill tax forms with Form $1770 \mathrm{~S}$ and 1770SS using efiling conducted at the tax office and tax booths in two malls provided by DGT during February and March 2019 in Jakarta. Valid samples in this study were 93 respondents. The methodology of this research is quantitative. The methodology used is quantitative which is processed using structural equation modeling (SEM) analysis of the LISREL 8.70 program.

Based on research model, object to be examined isuse of the actual system as a dependent variable 2 or Y2 and behavior intentions used well as dependent variable/moderation 1 or Y1. While the independent variable 1 is perceived useful as $\mathrm{X} 1$ and variable 2 is perceived ease to use as $\mathrm{X} 2$. Therefore, research hypothesis is as follows.

Table 1. Hypothesis

\begin{tabular}{c|l}
\hline Hypothesis & \multicolumn{1}{c}{ Description } \\
\hline $\mathrm{H}_{1}$ & Perception useful influence on behavior intentions used \\
\hline $\mathrm{H}_{2}$ & Perception of ease influences behavior intentions used \\
\hline $\mathrm{H}_{3}$ & $\begin{array}{l}\text { Perception useful, perceived ease to use together influences } \\
\text { behavior intentions used }\end{array}$ \\
\hline $\mathrm{H} 4$ & Behavior intentions used affect use of the actual system \\
\hline $\mathrm{H} 5$ & Behavior intentions used affect use of the actual system \\
\hline
\end{tabular}

\section{$3 \quad$ Result and Discussion}

Structural equation modeling is used to determine the structural relationship between the research variables. Test the suitability of the variable relationship structure using the goodnessof-fit index. The results of structural equation modeling (SEM) using the LISREL 8.70 program in this research in Table 2.

Table 2. Match MeasurementIndices

\begin{tabular}{lcc}
\hline IndicatorGOF & Expected size & Estimated Results \\
\hline & GFI $>0.90$ & 0.87 \\
RMSEA & RMSEA $<0.08$ & 0.08
\end{tabular}




\begin{tabular}{lll}
\hline NNFI & NNFI $>0.90$ & 0.94 \\
NFI & NFI $>0.90$ & 0.95 \\
AGFI & AGFI $>0.90$ & 0.72 \\
RFI & RFI $>0.90$ & 0.84 \\
IFI & IFI $>0.90$ & 0.96 \\
CFI & CFI $>0.90$ & 0.96 \\
\hline
\end{tabular}

Source: Data processed with Lisrel 8.70, 2019

This research has 3(three) hypotheses tested, from the 3 hypotheses base don the test results obtained that only the first hypothesis (H1), and seven (H7). The full results of testing each hypothesis in Table 3.

Table 3. Hypothesis Testing Results

\begin{tabular}{clc}
\hline Hypothesis & \multicolumn{1}{c}{ Description } & \multicolumn{1}{c}{ Conclusion } \\
\hline $\mathrm{H}_{1}$ & $\begin{array}{l}\text { Perceptionusefulinfluenceon behavior intentions } \\
\text { used }\end{array}$ & Hypothesisaccepted \\
H2 & $\begin{array}{l}\text { Perception of ease influencesbehavior intentions } \\
\text { used }\end{array}$ & Hypothesisrejected \\
H3 & $\begin{array}{l}\text { Perceptionuseful, Perceivedease to use together } \\
\text { influences behavior intentions used }\end{array}$ & Hypothesisaccepted \\
H4 & Behavior intentions usedaffectuse of the actual & Hypothesisrejected \\
H5 & Behavior intentions used affectuse of the actual & Hypothesisaccepted \\
\hline
\end{tabular}

Source: Data processed with Lisrel 8.70, 2019

The results of analysis using by Lisrel 8.70 $(0.1 \quad(0.11)$ 1.50 software program according to Figures 2 and 3 and Table 2 above, for the structural equation model, are presented in the following structural equation:

Behavioral intention to use $=$

Beh_Inte $=0.59 *$ Perce_Us $+0.16 *$ Perce_Ea, Errorvar. $=0.14, \mathrm{R}^{2}=0.50$

Based on equation 1 above, for the loading factor (path coefficient) the perceptionuseful variable 0.59 ; Perception of Use 0,16. The relationship betweenperception useful, perception of ease variables is shown in the structuralmodel in Fig 1 and Fig 2 below.

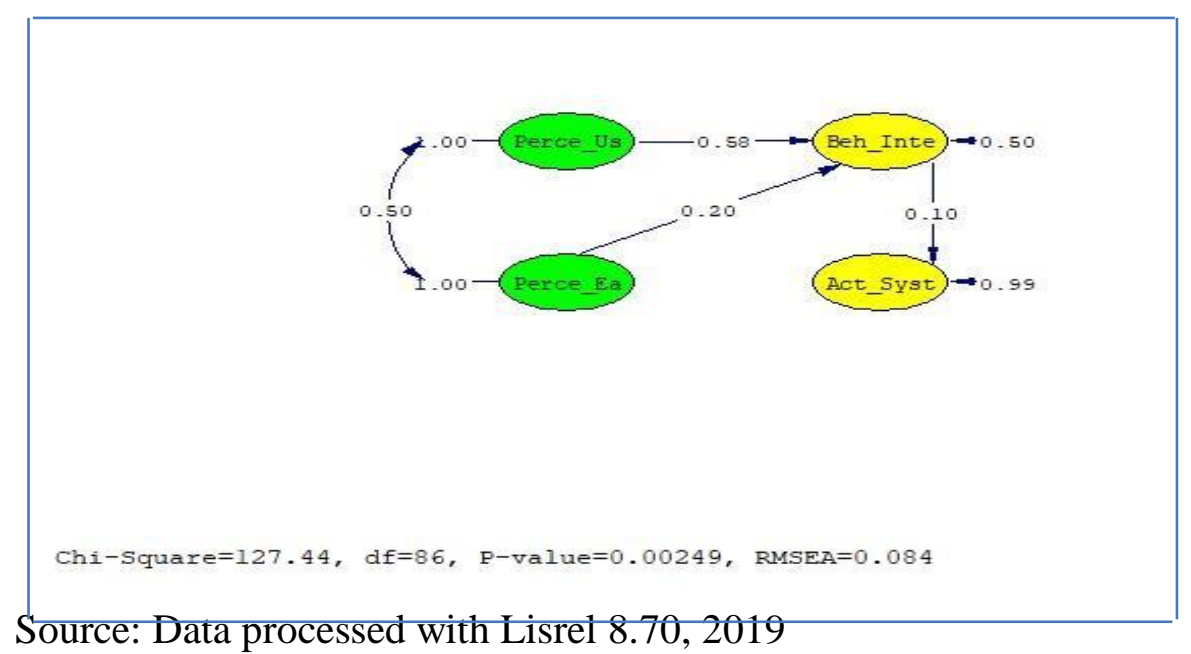

Fig 2. Structural Model Hypothesis 3 (Standardized) 


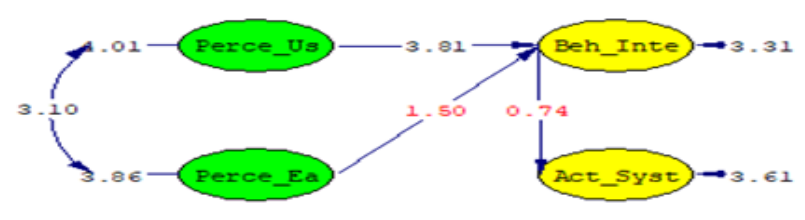

Chi-Square=127.44, df=86, P-value=0.00249, RMSEA=0.084

Source: Data processed with Lisrel 8.70, 2019

Fig 3. Structural Model Hypothesis 4 (t-values)

Based on the picture above, the calculated $\mathrm{F}$ value> $\mathrm{F}$ table perceptionuseful, perception of ease simultaneously against behavior intentions used3.31> 2.46, meaning that Perceived

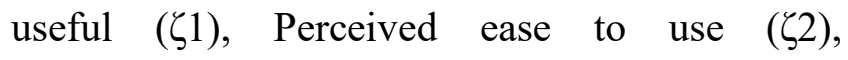
together- the same effect on behavior intentions used $(\eta 1)$ positive and significant effect together behavior intentions used $(\eta 1)$. Coefficient determination (R2)0.50, this value indicates contribution of $50 \%$ simultaneously exogenous variables Perceived useful, perception of easecan explain the diversity of variables endogenous behavioral intention to use, while the remaining $50 \%$ is influenced by other factors such as security data and can still report conventional Annual Tax Return.

Hypothesis five (H5) describes testing about the effect of exogenous variables: behavior intentions used $(\zeta)$ onuse of the actual system ( $\eta 2)$. The results of the Lisrel 8.70 software program data according to Figures 2 and 3 and the table above, for the structural equation model, are presented in the following structural equation.

Act_Syst $=0.13 *$ Beh_Inte, Errorvar. $=0.43, \mathrm{R}^{2}=$ 0.011
$(0.17)$
0.74

Based on equation 2 above, the loading factor (path coefficient) behavior intentions usedvariableis 0.13 . Lisrel 8.70 software program according to Figures 2 and 3 and the table above, the calculated $F$ value of the effectsimultaneous behavior intentions usedonuse of the actual system is $3.61>2.46$ so that it can be said to be influential and significant behavior intentions used against use of the actual system. Coefficient determination (R2) of 0.011 , the value shows that the magnitude of the simultaneous contribution of the behavior intentions used variable to the use of the actual system $1.1 \%$, rest is influenced by other factors by $98.9 \%$ as there is still a lack of awareness of taxpayers in meeting their tax obligations. This means that in other words whatever the government does ithis case the Directorate General of Taxes especially regarding tax reporting, taxpayers carry out because they are forced as the meaning of taxation that can be forced based on the law.

\section{Conclusion}

The results showed that partially showed that perceived useful influence and significant effect onbehavior intentions used. Perception of easehas an effect but is not significant onon behavioral intention used. Behavioral intention used has an effect but is not insignificant to the Use of the Actual System. Results of study simultaneously that perceived useful, Perception of ease and 
significant influence on behavioral intention used. Coefficient determination (R2) of 0.50 , this value indicates that the contribution of $50 \%$ simultaneously exogenous variables Perceived useful, Perception of ease can explain diversity variables endogenous behavioral intention to use, such as security data and can still report conventional Annual Tax Return.

The magnitude of the simultaneous contribution of the Behavioral intention used variable to the use of the actual system $1.1 \%$, rest is influenced by other factors of $98.9 \%$ such as the lack of awareness of taxpayers in meeting their tax obligations. This means that in other words whatever the government does in this case the Directorate General of Taxes in particular regarding tax reporting, the taxpayer carries out his tax obligations because he is forced as the tax sense that can be forced based on the law.

Tax institution, continues to improve and add to the benefits of the attractiveness of e filling. As done in India, namely the process of filing a tax refund if it does not carry out e-filing, it is not processed or processed but does not get additional interest as stipulated in the General Taxation Provisions Act.

\section{References}

[1] Laporan Kinerja Direktorat Jenderal Pajak Tahun 2017 dan 2018.

[2] Nur, Muhammad: Upaya Legal Membuat Perencanaan PajakMelalui PemanfaatanCelah Celah dan Fasilitas Kebijakan Perpajakan, 2001.

[3] Jyoti, Arora : E-Filing Of Income Tax Returns In India .An Overview Scholarly Research Journal for Humanity Science \& English Langauage, ISSN : 2348.3083, 2014.

[4] Azmi, Anna, A. Che, andKamarulzaman, Yuniza : Adoption of tax e-filing: A conceptual paper. African Journal of Business Management Vol. 4(5), pp. 599603, May 2010.ISSN 1993-8233, 2010.
[5] Davis, F. D., Bagozzi, R. P., \&Warshaw, P. R :User Acceptance of Computer Technology: A Comparison of Two Theoretical Models. Management Science, 35(8), 982-1003,1989.

[6] https://www.pajak.go.id/id/informasi-efiling-melalui-website-direktorat-jenderalpajak

[7] https://www.jurnal.id/id/blog/2017manfaat-melakukan-lapor-pajak-secaraonline/.

[8] https://www.pajak.go.id/id/electronicfiling. 